\title{
The Process of Forming Accounting Policies of Ukrainian Enterprises by International Financial Reporting Standards
}

\author{
Valentyna Panasyuk ${ }^{1}$, Nina Ovsiuk ${ }^{2, *}$, Ruslan Volchek ${ }^{3}$, Grygorii Azarenkov ${ }^{4}$, \\ Nataliia Volenshchuk ${ }^{5}$, Olena Tyvonchuk ${ }^{6}$ \\ ${ }^{1}$ Department of Accounting and Taxation, Western Ukrainian National University, Ternopil, Ukraine \\ ${ }^{2}$ Department of Accounting and Auditing, National Aviation University, Kyiv, Ukraine \\ ${ }^{3}$ Department of Accounting and Auditing, Odessa National Economic University, Odesa, Ukraine \\ ${ }^{4}$ Department of Accounting and Business Consulting, Simon Kuznets Kharkiv National University of Economics, Kharkiv, Ukraine \\ ${ }^{5}$ Deputy Director for Research, Donetsk State Agricultural Science Station of NAASU, Pokrovsk, Ukraine \\ ${ }^{6}$ Department of Accounting and Analysis, Lviv Polytechnic National University, Lviv, Ukraine
}

Received June 8, 2021; Revised August 18, 2021; Accepted August 30, 2021

\section{Cite This Paper in the following Citation Styles}

(a): [1] Valentyna Panasyuk, Nina Ovsiuk, Ruslan Volchek, Grygorii Azarenkov, Nataliia Volenshchuk, Olena Tyvonchuk, "The Process of Forming Accounting Policies of Ukrainian Enterprises by International Financial Reporting Standards," Universal Journal of Accounting and Finance, Vol. 9, No. 5, pp. 1199 - 1211, 2021. DOI: 10.13189/ujaf.2021.090529.

(b): Valentyna Panasyuk, Nina Ovsiuk, Ruslan Volchek, Grygorii Azarenkov, Nataliia Volenshchuk, Olena Tyvonchuk (2021). The Process of Forming Accounting Policies of Ukrainian Enterprises by International Financial Reporting Standards. Universal Journal of Accounting and Finance, 9(5), 1199 - 1211. DOI: 10.13189/ujaf.2021.090529.

Copyright $\odot 2021$ by authors, all rights reserved. Authors agree that this article remains permanently open access under the terms of the Creative Commons Attribution License 4.0 International License

\begin{abstract}
In most countries of the world, business entities independently determine their accounting policies, choose the form of accounting, synthetic and analytical accounts, forms of primary documents, and organize an internal control system. In this case, it is necessary to be guided by the legislation requirements, which is not always perfect and consistent. According to the accounting policy, the consequence of the deficiencies in legislative regulation was its ineffective implementation and use by enterprises in practice. This, in turn, negatively affects the efficiency of business entities as a whole. One way to solve this problem is to consider the organizational and technological features of the activities of enterprises as the basis for their development of accounting policies. The authors investigated when the standards should guide a company and when the creation of an accounting policy is reasonable. The study contains a theoretical and methodological substantiation of the directions, as well as the proposals themselves for the formation of the accounting policy of the enterprise, namely: a possible algorithm for the construction of the accounting policy of the plant by IFRS is presented, which represents the
\end{abstract}

process of forming the accounting policy of the enterprise; the analysis of IFRS norms is clearly shown since this is fundamental in the formation of the accounting; analyzed IFRS, according to which options and/or variability of which are due to the inconsistency of IFRS and justified the choice of one or another option. The proposed recommendations will attract more foreign investment and can facilitate the transition to IFRS for the company.

Keywords Accounting, Accounting Policies, International Financial Reporting Standards (IFRS)

\section{Introduction}

Cardinal socio-economic transformations are carried out in society aimed at forming a modern market economy in increasing international economic integration. The issues of reforming accounting and financial reporting by world standards are gaining particular relevance $[2 ; 4 ; 12]$. Since mutually beneficial international cooperation is 
based primarily on reliability, the criteria are transparent, objective and reliable financial reporting, which in turn is designed to become a tool for making effective management decisions. The International Financial Reporting Standards (IFRS), to a certain extent, provide financial reporting with such important qualities mentioned above.

This work aims to generalize the theoretical foundations of forming the enterprise's accounting policy and develop recommendations for constructing the accounting policy at the enterprise by international financial reporting standards.

\section{Methodology}

The authors conducted their research according to the following methodology (Fig. 1).

This methodology (figure 1) will allow for a more logical and structured presentation of the study.

\section{Literature Analysis}

Following the Law of Ukraine "On Accounting and Financial Reporting of Ukraine", the accounting policy is a set of principles, methods and procedures used by an enterprise to prepare financial statements [13].

The need to apply an accounting policy is associated with the protection of the interests of users of financial information of enterprises, since the reliability and completeness of the statements compiled on its basis depend on the chosen accounting methods and procedures, including indicators characterizing the financial and property status of the enterprise, and the results of activities.

The term "accounting policies" has been officially used in international practice since 1973, appearing in IAS 1 "Disclosure of accounting policies" and IFRS 5 "Information to be disclosed in financial statements". Since 1997, a new IAS 1 "Presentation of Financial Statements" has been in effect, issued based on these standards, which contains requirements for disclosure of information in accounting policies [7]. It is also worth noting IFRS 8 "Accounting policies, changes in accounting estimates and errors" [8], which contains requirements for disclosure of accounting information and practical recommendations for the application of standards and contributes to the harmonization of accounting standards and procedures related to the coverage of accounting policies in financial statements.

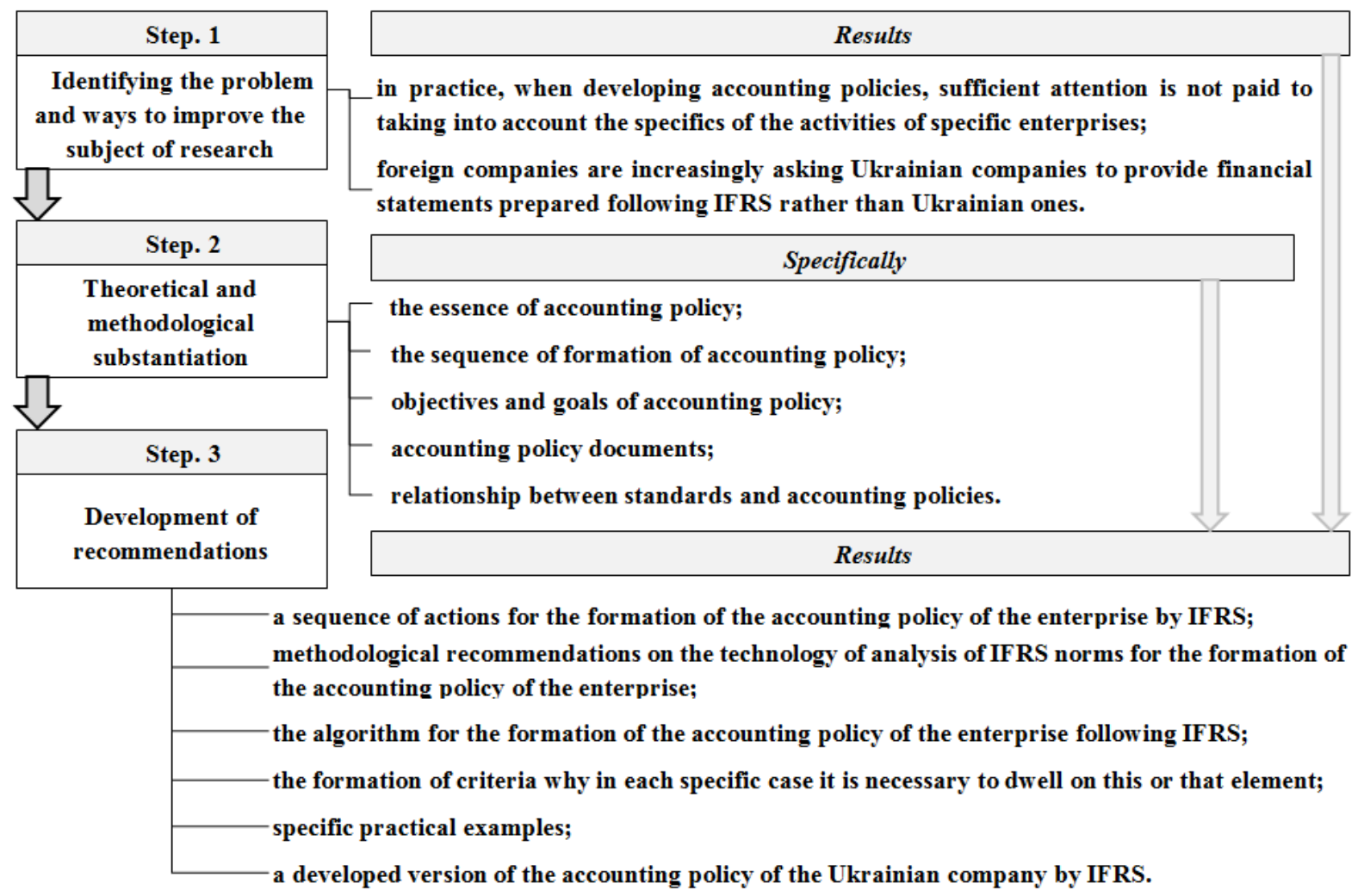

Figure 1. Research methodology 
The concepts of "principles", "methods", and "procedures" are in a particular hierarchy of each other. The principle of accounting is a rule that should be followed when measuring, evaluating and registering business transactions, reflecting their results in financial statements $[13 ; 15]$.

The accounting method is a technique that ensures the receipt, processing, and provision of accounting information $[1 ; 6]$. As for the "accounting procedure", there is no such definition in both domestic and foreign science. There are different assumptions of scientists, according to one of which (A. Welch, D. Short) accounting procedures are the embodiment of fundamental concepts [17]. In other words, with detailed rules that ensure the implementation of the accounting process - from the reflection of business transactions in primary documents to the preparation of financial statements (Table 1).

So, the principles should be adhered to when applying specific methods with the implementation of appropriate procedures. By the way, in our opinion, there is a proposal by $\mathrm{O}$. Khomin [10] regarding the use of the concept of "system" instead of "aggregate" to define "accounting policy", indicating the relationship between the categories discussed above.

In addition, since the principles of disclosure of accounting information are generally binding rules for all business entities, the question arises about the advisability of including them in the accounting policy as an opportunity to choose among alternative accounting and financial reporting methods. As you can see, the opinions of scientists on this matter were divided. Some $[3 ; 11]$ adhere to the traditional approach defined by law. Others do not include the principles of disclosing accounting information in the accounting policies of enterprises. The interpretation of the accounting policy is almost entirely identical, given in the Law of Ukraine and international standards. At the same time, the scope of its application is limited to the preparation of financial statements, focused mainly on meeting the needs of investors and creditors.

The definition of domestic scientists is much broader than the normative ones and covers the issues of maintaining and organizing accounting. Therefore, it is necessary to improve the current legislation, in this case on accounting policy, by introducing scientists' proposals, using international standards as a guide, and not copying them.

An important issue that has not been fully resolved today is the relationship between the concepts of "accounting policy" and "organization of accounting", which arises from their different interpretations. Some scientists consider the accounting policy as a methodological component of the accounting organization; others - the organization as part of the accounting policy, is a complex system [10]. Still, others bring these concepts as close as possible, defining them in a broad sense.

Table 1. Relationships between categories of accounting policies

\begin{tabular}{|c|c|c|c|c|}
\hline $\begin{array}{c}\text { Significant } \\
\text { Accounting Policies }\end{array}$ & \multicolumn{2}{|c|}{$\begin{array}{c}\text { Autonomy, continuous activity, periodicity, a single monetary measure, historical cost, accrual and } \\
\text { correspondence of income and expenses, completeness of coverage, prudence, the prevalence of essence over } \\
\text { form, constancy }\end{array}$} \\
\hline Accounting Methods & $\begin{array}{c}\text { Chronological and } \\
\text { systematic observation }\end{array}$ & $\begin{array}{c}\text { Measurement of household } \\
\text { assets, processes }\end{array}$ & Current groupings & Final synthesis \\
\hline \multirow{2}{*}{$\begin{array}{c}\text { Accounting } \\
\text { techniques }\end{array}$} & Documenting & Evaluation & Accounts & Balance \\
\cline { 2 - 5 } & Inventory & Calculation & Double entry & Financial statements \\
\hline $\begin{array}{c}\text { Accounting } \\
\text { procedures }\end{array}$ & $\begin{array}{c}\text { Collection, search, } \\
\text { registration, verification of } \\
\text { information }\end{array}$ & $\begin{array}{c}\text { Measurement, evaluation, } \\
\text { calculation }\end{array}$ & $\begin{array}{c}\text { Classification, } \\
\text { processing, partial } \\
\text { generalization }\end{array}$ & $\begin{array}{c}\text { Complete generalization, } \\
\text { information storage }\end{array}$ \\
\hline
\end{tabular}




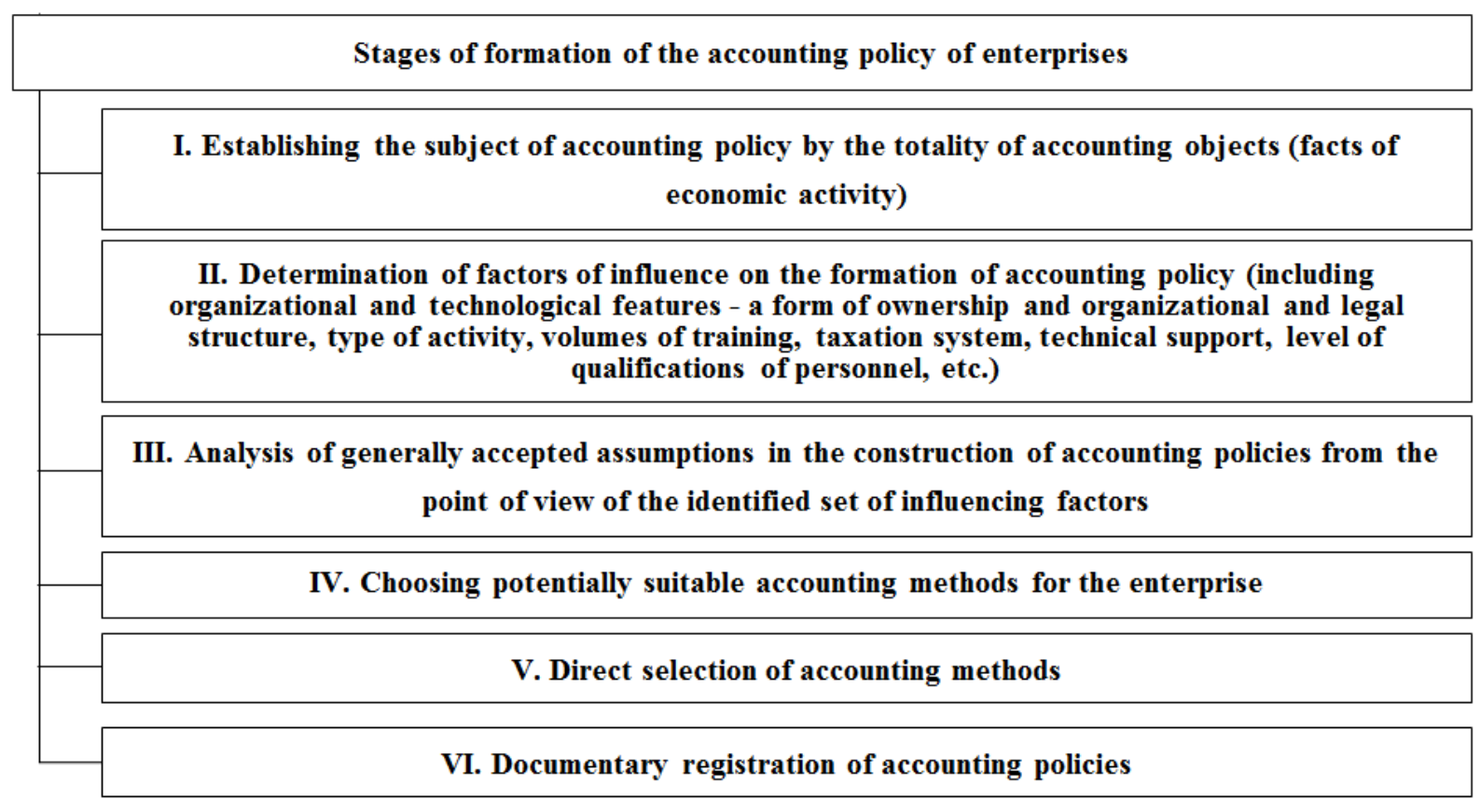

Figure 2. Consistency of the formation of accounting policies

The purpose of the accounting policy is to regulate the rules of accounting and financial

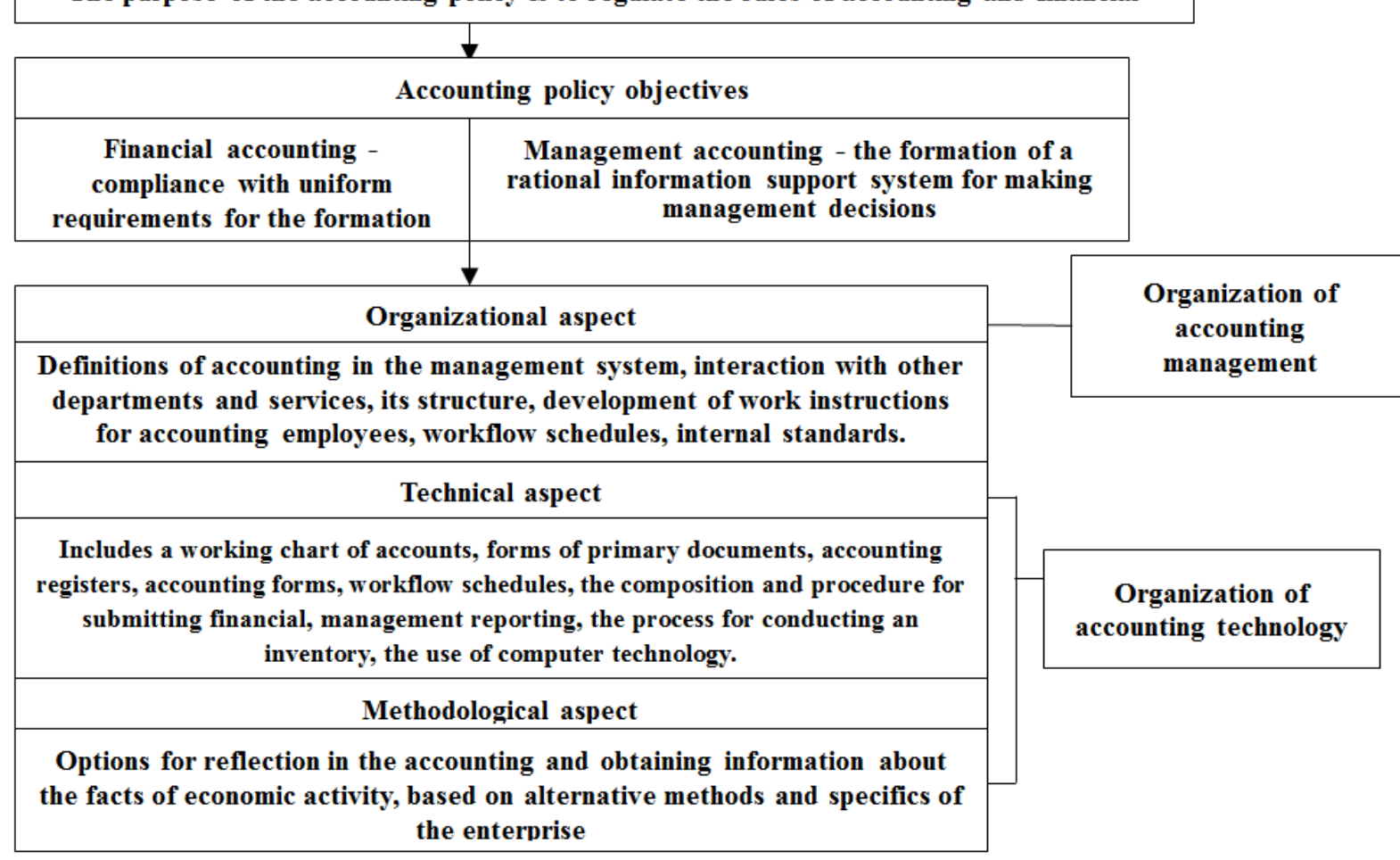

Figure 3. The structure of the accounting policy of the enterprise

At the heart of the rational construction of accounting and control at enterprises, it accounts for the specifics of their activities, organizational and technological characteristics. The need to fully reflect on the latter determines the most optimal variant of the accounting policy. The sequence of formation of the accounting policy of the enterprise can be represented in the form of the following scheme (Fig. 2).

In our opinion, the most correct is the last approach, according to which the accounting policy is not only a set of methods to generate reports but also a tool for organizing and managing accounting at an enterprise (Fig.3).

In practice, when developing accounting policies, 
sufficient attention is not paid to taking into account the specifics of the activities of specific enterprises. Therefore, a common approach to creating and applying accounting policies, in turn, is reflected in the incorrect documenting of the latter.

As a rule, the accounting policy is governed by the order on the accounting policy of the enterprise, containing a description of the methodological principles for the technique and organization of accounting. However, this document should not become the only one, but only the main one in harmonizing accounting rules, drawing up financial statements at the enterprise. The order should be supplemented with internal regulations, instructions regulations, regulations, decisions of owners, and the like. In addition, at each enterprise, project documentation for the construction of accounting must be developed and approved, which includes workflow schedules, an accounting organization plan, accounting automation projects, and others that provide documentation of not only acceptable methods of accounting, financial reporting but also the means of their implementation [14].

Thus, in most countries of the world, business entities independently determine their accounting policy, choose the form of accounting, synthetic and analytical accounts, forms of primary documents, and organize an internal control system. In this case, it is necessary to be guided by the requirements of the legislation, which is not always distinguished by perfection and consistency. According to the accounting policy, the consequence of the deficiencies in legislative regulation was its ineffective implementation and use by enterprises in practice. This, in turn, negatively affects the efficiency of business entities as a whole. One way to solve this problem is to consider the organizational and technological features of the activities of enterprises as the basis for their development of accounting policies.

\section{Theoretical Foundations of the Formation of Accounting Policies at the Enterprise}

Taking into account $\S \S 8$ and 10 of IAS 8 [8], the relationship between standards and accounting policies can be represented in the form of a diagram (Fig. 4).

So, the accounting policy takes place only when the standards:

- several options are provided within one rule;

- no option is provided (due to the lack of a corresponding IFRS).

The relationship (ratio) of accounting policies with the standards is defined in clause $1.2 \mathrm{p}$. I Methodical recommendations on the accounting policy of the enterprise, approved by order of the Ministry of Finance of Ukraine dated 27.06.13, No. 635, according to which the enterprise determines the accounting policy independently, but based on national standards. These recommendations should be viewed as a kind of checklist, a list of issues that need to be addressed when developing an accounting policy or analyzing it for improvement. The document's name and the wording are given in clause 1.1 p. I testify to its recommendatory nature. It can be applied by enterprises, organizations and other legal entities, regardless of the organizational and legal forms of management and forms of ownership. The Ministry of Finance itself, in the same paragraph $1.1 \mathrm{p}$. I do not advise banks, budgetary institutions, and enterprises that, according to the legislation, apply international financial reporting standards to use Method Recommendations No. 635.

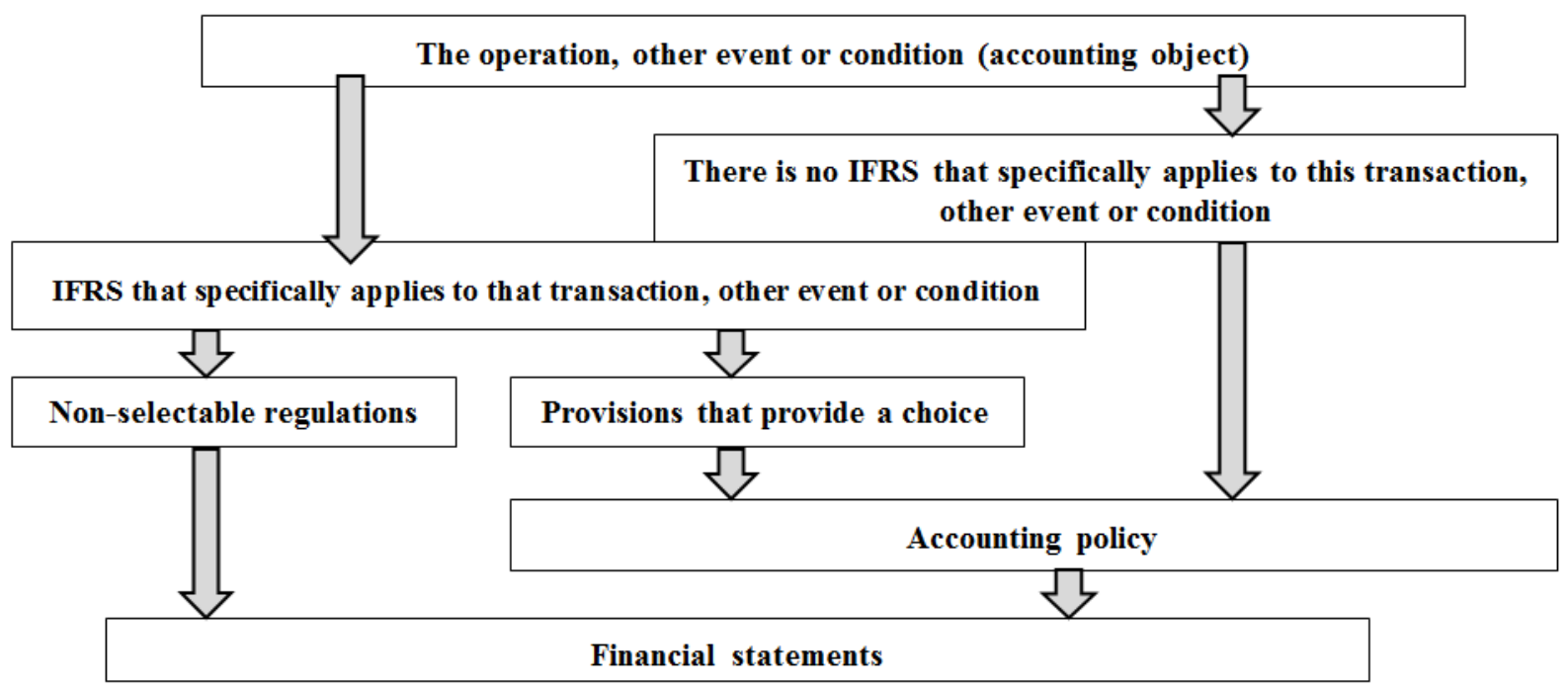

Figure 4. Relationship between standards and accounting policies 


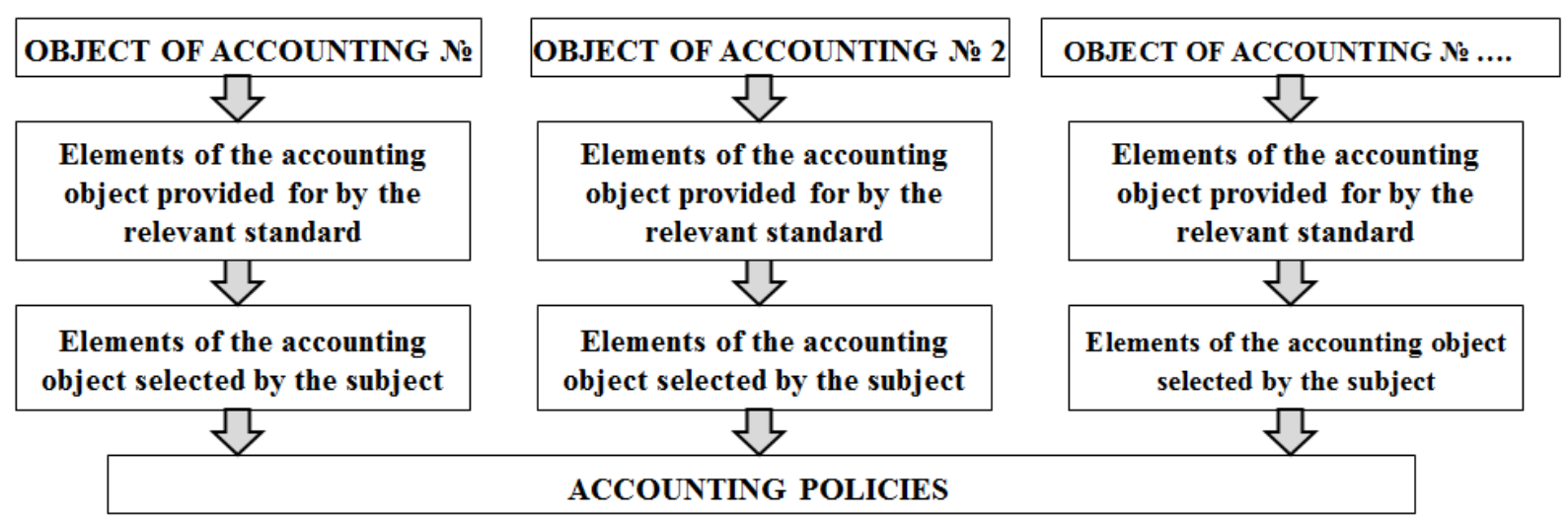

Figure 5. Accounting policy formation scheme

It is necessary to determine the sequence of actions to form the enterprise's accounting policy correctly. First of all, it is essential to establish what business operations the enterprise is carrying out or plans to carry out shortly. Accounting objects already exist or may appear at the enterprise soon. After that, it is necessary to determine which standards correspond to these operations and objects and carefully study them, paying attention to the norms providing the possibility of choice $[2 ; 14]$.

But if an alternative exists, there should be appropriate criteria in favour of applying a particular element of accounting policy. This question is the most difficult; therefore, there are very few practical recommendations on it. However, some criteria are given directly in the standards.

The Ministry of Finance advises (in clause 1.3, p. I of Methodology No. 635) to include in the order on accounting policy only those elements for which more than one of their options is provided by regulatory legal acts on accounting. At the same time, it is not advisable to include univariate assessment methods, accounting and procedures in such an administrative document. This statement requires clarification. In fact, you do not always have to choose between the proposed options (such as the choice of the depreciation method). Sometimes the choice is whether or not to apply specific procedures or techniques. For example, whether or not to re-evaluate.

In general, the accounting policy formation scheme may look like this (Fig. 5).

This scheme can be used as the basis for the formation of accounting policies. But it must be borne in mind that two points are not taken into account in it:
- firstly, speaking about accounting policies, one cannot avoid the issue of accounting estimates;

- secondly, accounting objects are often heterogeneous, therefore, within each of them, certain groups can be distinguished, and for each group, different elements of accounting policy can be selected.

That is, the scheme for the formation of accounting policies, if you approach this process seriously and responsibly, will have a more complex structure.

\section{Results: Development of Recommendations for the Formation of Accounting Policies by International Financial Reporting Standards}

Because financial statements prepared following IFRS are more understandable and acceptable for a foreign investor, the improvement of the accounting policy of the enterprise by IFRS is vital.

According to IFRS, it is not required to approve the accounting policy of the enterprise as a separate organizational and administrative document. However, its content should be set out in the form of a particular document or the notes to the financial statements of business entities by an approved order or other internal administrative documents.

Figure 6 shows a possible algorithm for forming an enterprise's accounting policy according to IFRS. 


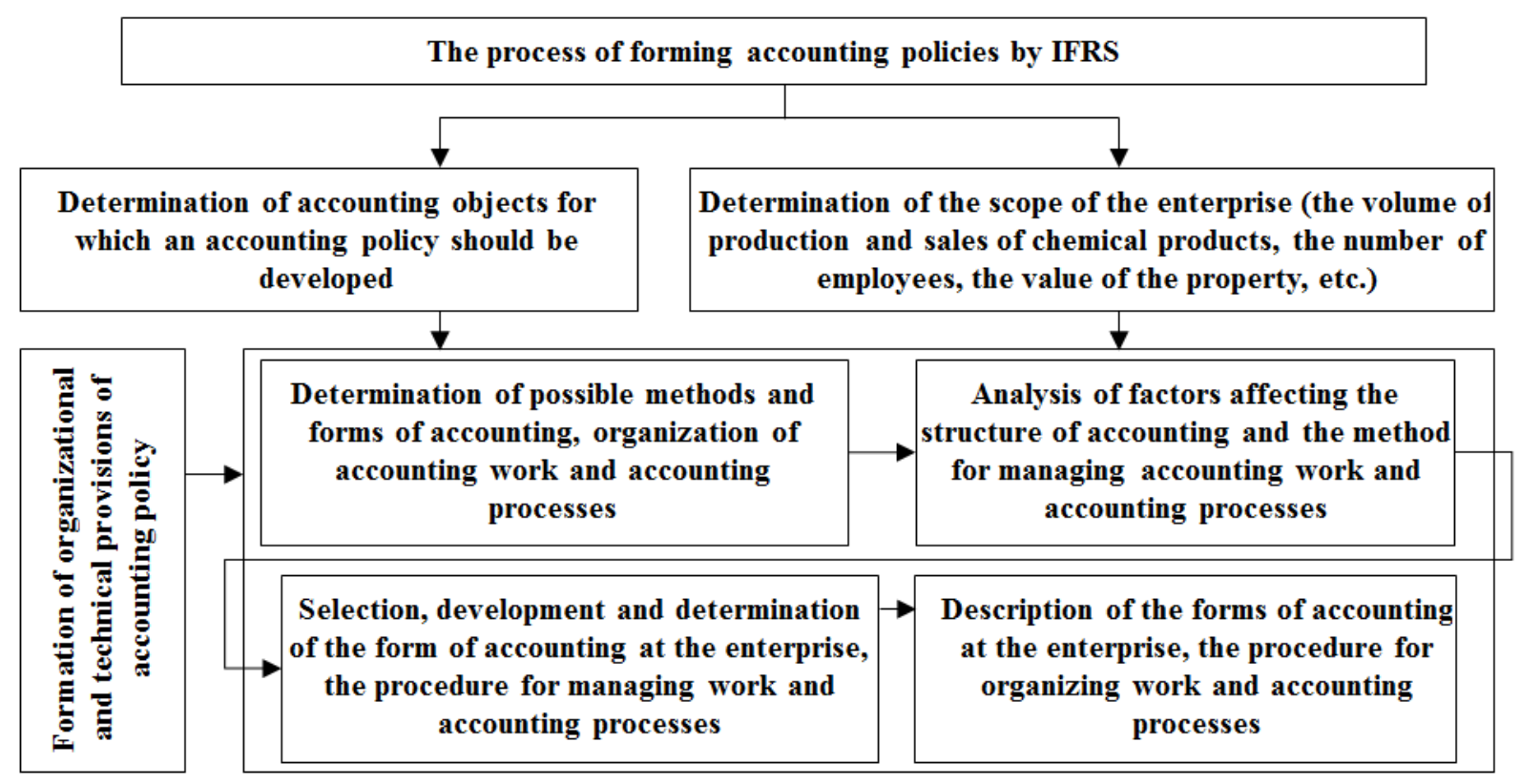

Figure 6. The process of forming the accounting policy of the enterprise by IFRS

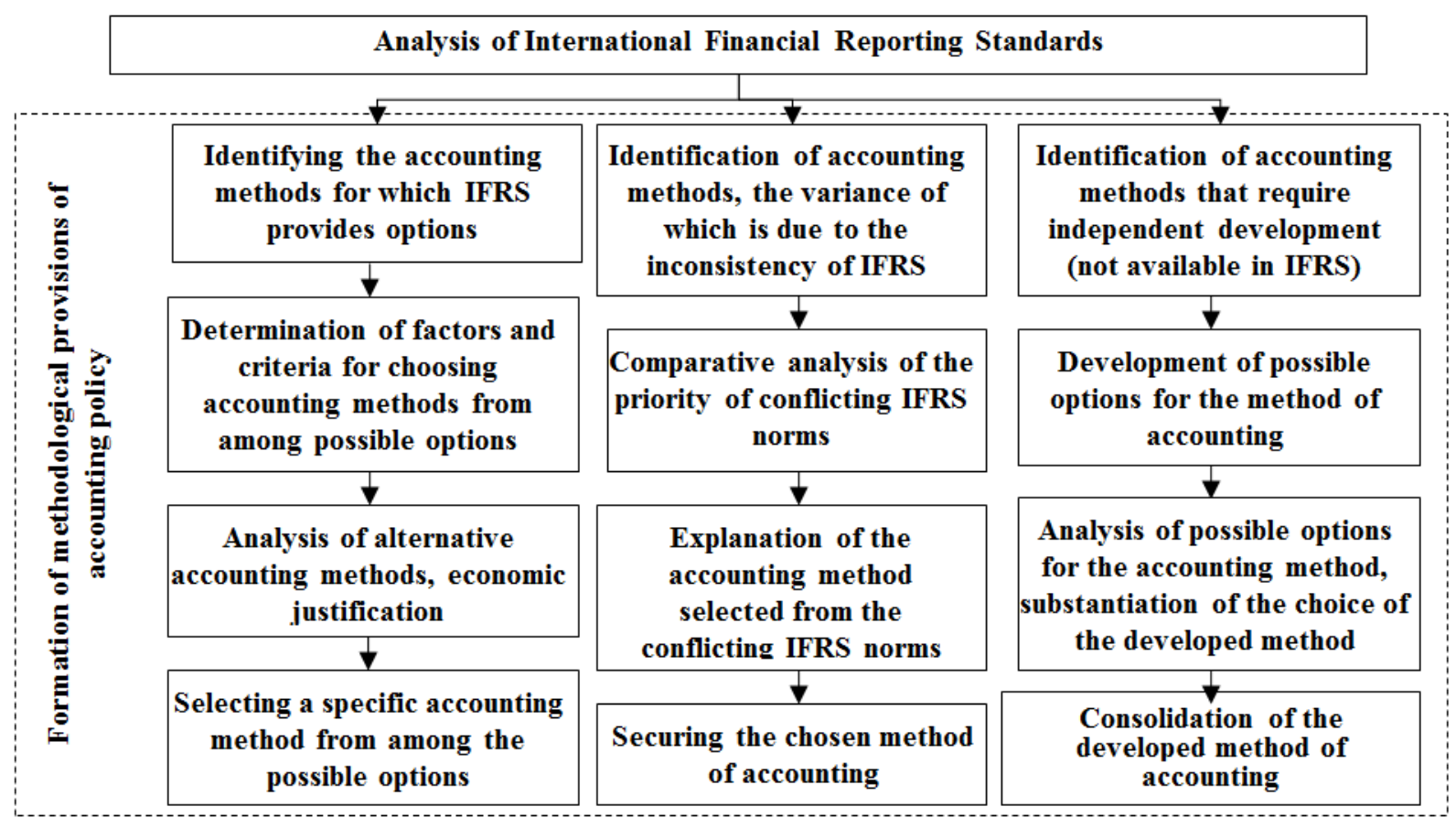

Figure 7. Analysis of IFRS norms

The process of forming an accounting policy should be based on the analysis of a large number of regulatory documents in the field of international accounting regulation and constant monitoring of their changes (Fig. 7).

Thus, Fig. 6-7 needs to be analyzed IFRS. Let's comment on some of the selected options:

- valuation of fixed assets (basis: IAS 16, clause 29 [9]). Assessment of fixed assets after their recognition in accounting is carried out according to a) actual cost or b) revalued cost.
We choose an assessment based on the actual cost price, because this method is the least labour-intensive. The cost model is based on the initially recognized cost of property, plant and equipment, i.e. the actual costs of their acquisition, as a basis for determining their book value.

In case of revaluation of one item from any group of fixed assets, the company must revalue all items included in this group (IAS 16.36).

- the method of changing the accrued depreciation when revaluing fixed assets (basis: IAS 16, clause 35). 
Accumulated depreciation of property, plant and equipment at the revaluation date:

a) restated in proportion to the change in the gross carrying amount of the asset in such a way that the carrying amount of the asset after revaluation was equal to its revalued amount;

b) is deducted from the gross carrying amount of the asset, and the net amount is restated to the revalued amount of the asset.

We choose the first option because this method is usually applied when an item is revalued to amortized replacement cost by using a conversion (indexing) factor. Depreciation accumulated before revaluation is written off to capital gains on revaluation, increasing the revaluation reserve for the item. Thus, the netbook value from the moment of revaluation becomes the gross book value, and, accordingly, depreciation begins to accumulate again for this item. This method is usually used in the reassessment of buildings, and this type of asset in the structure is not the main one.

- the method of transferring the reserve from the revaluation of fixed assets to retained earnings (basis: IAS 16, paragraph 41). The transfer of the account from the revaluation of fixed assets to retained earnings is made:

a) upon disposal of the asset;

b) during the operation of the asset.

Choosing the option upon disposal of the asset if a portion of the revaluation surplus is transferred to retained earnings as the asset is used, the amount of the excess carried is the difference between the depreciation calculated based on the revalued carrying amount of the asset and the depreciation calculated based on the original cost of the asset. The transfer of the revaluation surplus to retained earnings is made without involving profit or loss accounts.

- the method of calculating the depreciation of fixed assets (basis: IAS 16, clause 62). Depreciation of fixed assets is charged: a) straight-line method; b) the method of decreasing balance; c) by the method of writing off the cost in proportion to the volume of production (method of units of production).

We choose the last option - the method of production units because the straightforward method is advisable to apply for those types of fixed assets where time, and not obsolescence (obsolescence), is the main factor limiting the service life. With the diminishing balance method, the initial cost will never be written off, a) by the method of writing off the cost in proportion to the volume of production, it is used where the depreciation of fixed assets is directly related to the frequency of their use, which is typical for the studied enterprise.

- accounting for investment property (basis: IAS 40, paragraph 30 ). Investment property is accounted for: a) at fair value; b) at actual costs (except for real estate).

We select at fair value as the most appropriate one, since initial valuation is based on actual acquisition costs; subsequent measurement and accounting - all items are measured at fair value, except in exceptional cases; recognition of changes in fair value - gains (losses) from changes in fair value are charged to net profit or loss for the period in which they arise, i.e. reflected in the income statement; depreciation is not charged; in exceptional cases, when it is not possible to determine the fair value for accounting for an investment property, the accounting model at historical cost is used, the residual value is assumed to be zero; impairment - the provisions of IAS 36 are not applied (they have already been implemented as fair value accounting is used).

- estimation of the cost of reserves (basis: IAS 2, paragraph 25). Estimating the cost of funds is carried out: a) by the FIFO method; b) the weighted average cost method.

We choose the weighted average cost method since this method is easy to use and entirely accurate. It considers the average price of inventories, and the FIFO method often underestimates the cost of disposing of stocks and overestimates the cost cost-profit of the enterprise. Therefore, this method is beneficial for the state for fiscal purposes and leads to a larger income tax payment.

- components of cash and cash equivalents (basis: IAS 7, paragraphs 7-9, 45). Consider as cash equivalents: a) short-term investments (up to 3 months); b) bank overdrafts.

We choose both options.

- the present value of expected payments under the pension plan (basis: IAS 26, paragraph 23). The present value of expected payments under the pension plan is calculated and reported: a) based on current salary levels; b) based on projected salary levels before the plan participants' retirement.

We select option A (based on current salary levels). Since ADSPP, being the sum of the values currently attributable to each participant in the plan can be calculated more objectively than according to the projected salary levels, since it contains fewer assumptions; The increase in pensions associated with an increase in wages becomes a liability of the pension plan at the time of the rise in wages; The amount of the actuarial present value of promised benefits, based on current salary levels, is generally more closely related to the amount payable if the plan is terminated or liquidated; Disclosed in the statements of the pension plan to show the obligation for the pension earned as of the reporting date. 
- the format of disclosure of information for pension plans with defined benefits (base: IAS 26, paragraph 28).

a) The financial statements include a statement showing the benefit plan's net benefit plan, the actuarial present value of promised retirement benefits, and the resulting excess or deficit. The plan's financial statements also contain statements of changes in the net assets of the plan that are the source of benefits and changes in the actuarial present value of promised retirement benefits. The financial statements may be accompanied by a separate actuarial report supporting the actuarial present value of promised retirement benefits;

b) financial statements, which include a statement of the net assets of the pension plan serving as a source of payments and a notice of changes in the net assets of the pension plan serving as a source of income. The actuarial present value of promised retirement benefits is disclosed in the notes to the statements. The financial information may be accompanied by an actuary's report justifying the current actuarial value of promised retirement benefits;

c) financial statements, which include a statement of the net assets of the pension plan serving as a source of benefits and a view of changes in the net assets of the pension plan serving as a source of help, the actuarial present value of promised retirement benefits are presented in a separate actuary's statement.

We choose the first option; the rationale is the same as in the previous paragraph.

- presentation of expenses in financial statements (basis: IAS 1 p.99,102-103). Expenses in the financial statements are presented in classification: a) based on the nature of expenses; b) by functional purpose of expenses (cost of sales).

The first form provides for a breakdown based on the nature of the costs. Expenses in the income statement are grouped according to their nature (for example, depreciation expenses, purchase of materials, transportation, employee benefits or advertising) and are not structured by different functional purposes within the organization; therefore, we consider it more suitable for the studied enterprise.

The second form is structured by functional purpose of expenses or based on "cost of sales". In this case, the costs are divided into the actual cost of sales, sales costs (commercial), and administrative (management) costs. At a minimum, an entity should disclose the cost of sales separately from other expenses. This method provides users with more meaningful information than the method of classifying costs based on their nature. Still, structuring costs by function may require arbitrary cost allocation and professional judgment, which includes a subjective factor.
- the form of the statement of profit or loss and comprehensive income (basis: IAS 1 clause 10A). The organization prepares: a) a single statement of comprehensive income, including a section on profit or loss; b) a separate statement of profit or loss and a separate statement of comprehensive income.

Option B is more labour intensive but more convenient to use and more informative for the purposes of the enterprise.

- presentation of items of other comprehensive income (basis: IAS 1 clause 91). The organization presents items of other total income: a) net of tax effects; b) before the relevant tax effects with the reflection of one amount for the aggregate amount of income tax in respect of these items.

We choose the first option as more straightforward because if an entity chooses option (b), it shall allocate the tax amount between those items that may subsequently be reclassified to profit or loss and those that will not subsequently be reclassified to profit or loss.

- presentation of assets in the "Statement of Financial Position" (basis: IAS 1, clause 63). Assets in the "Statement of Financial Position" are presented: a) with a division into short-term and long-term; b) in ascending order of asset liquidity; c) in descending order of asset liquidity.

A financial position statement reflects the value of an enterprise's assets, liabilities, and equity at the reporting dates. This is a crucial accounting statement in the IFRS system. In the RAS system, the analogue of this report is the balance sheet. We choose the first option because it is closer to Turkmen practice and other procedures for drawing up a statement of financial position are more applicable to financial institutions.

- a collapsed presentation of income and expenses (basis: IAS 1, paragraph 34-35). The organization presents in the financial statements on a net basis: a) positive and negative exchange rate differences; $b$ ) profits and losses arising from financial instruments held for trading; c) gains and losses from the disposal of long-term (non-current) assets, including investments and operating assets, by deducting the book value of the asset and the related costs of its sale from the proceeds from the disposal; d) the cost of creating provisions recognized by IAS 37 "Provisions, Contingent Liabilities and Contingent Assets" and recoverable under the terms of a contract with a third party net of the reimbursement received.

An entity presents both assets and liabilities and income and expenses separately. A collapsed presentation of items in the statement of comprehensive income or financial position, or in a separate income statement (if presented), unless such presentation reflects the substance of a transaction or other event, reduces the ability of users to 
understand transactions and other events and conditions that have arisen, and to estimate the future cash flows of the enterprise. The valuation of assets on a net basis fewer valuation reserves, such as reserves for obsolescence or allowances for doubtful accounts, is not considered a collapsed presentation.

34 IAS 18 Revenue defines revenue and requires it to be measured at the fair value of the consideration received or receivable, considering the amount of trade and wholesale rebates provided by the entity. In the ordinary course of business, the entity also other transactions that do not generate revenue but are ancillary to the main activity that generates revenue. The presentation of the results of such transactions is based on an aggregate production of income and related expenses arising from the same transaction, where such a presentation reflects the substance of the transaction or other event. For example, (a) gains and losses on disposal of non-current (non-current) assets, including investments and operating assets, are recognized by deducting the carrying amount of the asset and the related costs of selling it from the proceeds from the disposal; and (b) provisioning costs recognized by IAS 37 Provisions, Contingent Liabilities and Contingent Assets and recoverable under the terms of a contract with a third party (for example, a supplier warranty agreement) may be presented on a net with the refund received. Therefore, the last option is the most acceptable.

Meanwhile, the accounting policy chosen by the organization has a significant impact on the value of indicators of production costs, profits, taxes on profit, value-added, indicators of the organization's financial condition. Consequently, the accounting policy of the organization is an essential means of forming the value of the leading indicators of the organization's activities, tax planning, pricing policy. Without familiarization with the accounting policy, it is impossible to carry out a comparative analysis of the performance indicators of an organization for different periods, and even more so, a comparative study of various organizations.

An entity must also disclose the following, if not disclosed elsewhere in information published with the financial statements:

a) the legal address and legal form of the organization, the country of its legal registration and the address of the registered office (or the principal place of business, if it differs from the address of the registered office);

b) a description of the nature of operations and the main activities of the organization;

c) the name of the parent organization and the primary parent organization of the group;

d) the number of employees at the end of the period or the average number of employees during the period.

With the amendments and additions made, the accounting policy of the organization is reapproved by a commission of specialists from accounting, financial, technical departments, lawyers and other competent specialists, based on the characteristics of the organization's activities, and is approved by the relevant internal regulatory documents (order, order, etc.).

Considering the above, we present the developed version of the accounting policy of the enterprise by IFRS (Table 2).

Table 2. Provisions of the accounting policy of the enterprise.

\begin{tabular}{|c|l|c|}
\hline Accounting policy statement & Approved option & Base \\
\hline Valuation of fixed assets & $\begin{array}{l}\text { Valuation of fixed assets after their recognition in accounting is carried out at actual } \\
\text { cost. }\end{array}$ & $\begin{array}{c}\text { IAS 16, } \\
\text { p 29 }\end{array}$ \\
\hline $\begin{array}{c}\text { The method of transferring the allowance } \\
\text { from the revaluation of property, plant } \\
\text { and equipment to retained earnings }\end{array}$ & $\begin{array}{l}\text { The transfer of the allowance for revaluation of property, plant and equipment to } \\
\text { retained earnings is made upon disposal of the asset. }\end{array}$ & $\begin{array}{c}\text { IAS } 16, \\
\text { p.41 }\end{array}$ \\
\hline $\begin{array}{c}\text { Depreciation method for fixed assets } \\
\text { Measurement of intangible assets after } \\
\text { their recognition in the accounting }\end{array}$ & $\begin{array}{l}\text { Depreciation of property, plant and equipment is charged directly to production } \\
\text { unit of production method). }\end{array}$ & $\begin{array}{c}\text { IAS } 16, \\
\text { p.62 }\end{array}$ \\
\hline $\begin{array}{c}\text { Method of changing the accrued } \\
\text { depreciation when revaluing intangible } \\
\text { assets }\end{array}$ & $\begin{array}{l}\text { Accumulated amortization of intangible assets at the date of revaluation is restated } \\
\text { in proportion to the change in the gross carrying amount of the asset so that the } \\
\text { carrying amount of the asset after a revaluation is equal to its revalued amount. }\end{array}$ & $\begin{array}{c}\text { IAS } 38, \\
\text { p.80 }\end{array}$ \\
\hline $\begin{array}{c}\text { The method of transferring the reserve } \\
\text { from the revaluation of intangible assets } \\
\text { to retained earnings }\end{array}$ & $\begin{array}{l}\text { The transfer of the revaluation reserve for intangible assets to retained earnings is } \\
\text { made during the asset's life. }\end{array}$ & $\begin{array}{c}\text { IAS } 38, \\
\text { p.87 } 38,\end{array}$ \\
\hline $\begin{array}{c}\text { Amortization method for intangible } \\
\text { assets }\end{array}$ & Depreciation of intangible assets is charged on a straight-line basis. \\
\hline
\end{tabular}


Table 2. Continued

\begin{tabular}{|c|c|c|}
\hline Investment property accounting & Investment property is accounted for at fair value. & $\begin{array}{l}\text { IAS } 40 \text {, } \\
\text { p. } 30\end{array}$ \\
\hline Estimating the value of stocks & Inventories are estimated using the weighted average method. & $\begin{array}{l}\text { IAS } 2, \\
\text { p. } 25\end{array}$ \\
\hline Cash components and cash equivalents & $\begin{array}{l}\text { Consider as cash equivalents: short-term investments (up to } 3 \text { months); bank } \\
\text { overdrafts. }\end{array}$ & $\begin{array}{l}\text { IAS 7, } \\
\text { p.7-9, } \\
45\end{array}$ \\
\hline $\begin{array}{l}\text { Present value of expected benefits from } \\
\text { retirement benefit plan }\end{array}$ & $\begin{array}{l}\text { The present value of the anticipated benefits of the retirement benefit plan is } \\
\text { calculated and reported based on current salary levels. }\end{array}$ & $\begin{array}{l}\text { IAS } 26 \text {, } \\
\text { p. } 23\end{array}$ \\
\hline $\begin{array}{l}\text { Disclosure format for defined benefit } \\
\text { plans }\end{array}$ & $\begin{array}{l}\text { The financial statements include a statement showing the benefit plan's net benefit } \\
\text { plan, the actuarial present value of promised retirement benefits, and the resulting } \\
\text { excess or deficit. The plan's financial statements also contain statements of changes } \\
\text { in the net assets of the plan that are the source of benefits and changes in the } \\
\text { actuarial present value of promised retirement benefits. The financial statements } \\
\text { may be accompanied by a separate actuarial report supporting the current actuarial } \\
\text { value of promised retirement benefits. }\end{array}$ & $\begin{array}{l}\text { IAS } 26 \text {, } \\
\text { p. } 28\end{array}$ \\
\hline $\begin{array}{l}\text { Disclosure of government grants related } \\
\text { to assets in the statement of financial } \\
\text { position }\end{array}$ & $\begin{array}{l}\text { Government grants related to the acquisition of assets are recognized as deferred } \\
\text { income (deferred income) and subsequently charged to profit over the asset's life. }\end{array}$ & $\begin{array}{l}\text { IAS } 20 \text {, } \\
\text { p. } 24\end{array}$ \\
\hline Cash flow statement form & $\begin{array}{l}\text { The form of the statement of cash flows in terms of operating activities is drawn up } \\
\text { using the direct method, through which the main classes of cash payments and } \\
\text { receipts are reflected. }\end{array}$ & $\begin{array}{l}\text { IAS } 7, \\
\text { p. } 18\end{array}$ \\
\hline $\begin{array}{l}\text { Presentation of expenses in financial } \\
\text { statements }\end{array}$ & Expenses in the financial statements are classified based on the nature of the cost. & $\begin{array}{l}\text { IAS } 1 \\
\text { p. } 99,102 \\
-103\end{array}$ \\
\hline $\begin{array}{l}\text { Statement of profit or loss and } \\
\text { comprehensive income }\end{array}$ & $\begin{array}{l}\text { An entity prepares a separate report of profit or loss and a particular statement of } \\
\text { total income. }\end{array}$ & $\begin{array}{l}\text { IAS } 1 \\
\text { p.10A }\end{array}$ \\
\hline $\begin{array}{l}\text { Name of the statement of profit or loss } \\
\text { and comprehensive income }\end{array}$ & $\begin{array}{l}\text { Refer to the statement of profit, loss and other comprehensive income as the } \\
\text { statement of profit, loss and other components of complete financial result. }\end{array}$ & $\begin{array}{c}\text { IAS } 1 \\
\text { p. } 10\end{array}$ \\
\hline $\begin{array}{l}\text { Presentation of items of other } \\
\text { comprehensive income }\end{array}$ & An entity presents items of another comprehensive income net of tax effects. & $\begin{array}{c}\text { IAS } 1 \\
\text { p. } 91\end{array}$ \\
\hline $\begin{array}{l}\text { Foreign exchange differences on deferred } \\
\text { foreign tax liabilities or assets in the } \\
\text { statement of comprehensive income }\end{array}$ & $\begin{array}{l}\text { Foreign exchange differences on deferred foreign tax liabilities or assets are } \\
\text { recognized in the statement of comprehensive income as foreign exchange } \\
\text { differences. }\end{array}$ & $\begin{array}{l}\text { IAS } 12 \\
\text { p. } 78\end{array}$ \\
\hline Functional currency & The functional currency for the organization is UAH. & $\begin{array}{c}\text { IAS } 21 \\
\text { p. } 9\end{array}$ \\
\hline Presentation currency & $\begin{array}{l}\text { The organization prepares financial statements in the following currencies US } \\
\text { dollar. }\end{array}$ & $\begin{array}{c}\text { IAS } 21 \\
\text { p. } 39\end{array}$ \\
\hline $\begin{array}{l}\text { Translation of statements into the } \\
\text { presentation currency }\end{array}$ & $\begin{array}{l}\text { Income and expenses are translated to the presentation currency at the exchange } \\
\text { rates at the dates of the respective transactions. }\end{array}$ & $\begin{array}{c}\text { IAS } 21 \\
\text { p. } 39\end{array}$ \\
\hline $\begin{array}{l}\text { Reflection in the reporting of cash flow in } \\
\text { foreign currency }\end{array}$ & $\begin{array}{l}\text { Cash flows denominated in foreign currencies are reported at the appropriate } \\
\text { exchange rate between the functional and foreign currencies at the cash flow date. }\end{array}$ & $\begin{array}{l}\text { IAS } 7 \\
\text { p. } 25-27\end{array}$ \\
\hline $\begin{array}{c}\text { Disclosure of the amount of profit from } \\
\text { continuing operations and discontinued } \\
\text { operations attributable to owners of the } \\
\text { parent }\end{array}$ & $\begin{array}{l}\text { Income from continuing operations and discontinued operations attributable to the } \\
\text { owners of the parent is disclosed in the statement of comprehensive income. }\end{array}$ & $\begin{array}{c}\text { IFRS } 5 \\
\text { p.35d }\end{array}$ \\
\hline $\begin{array}{l}\text { Presentation of assets in the "Statement of } \\
\text { Financial Position" }\end{array}$ & $\begin{array}{l}\text { Assets in the Statement of Financial Position are presented with a division into } \\
\text { short-term and non-current. }\end{array}$ & $\begin{array}{l}\text { IAS } 1 \text {, } \\
\text { p.63 }\end{array}$ \\
\hline
\end{tabular}


Table 2. Continued

\begin{tabular}{|c|c|c|}
\hline Collapsed view of income and expenses & The organization presents in the financial statements collapsed: & $\begin{array}{l}\text { IAS 1, } \\
\text { p.34-35 }\end{array}$ \\
\hline $\begin{array}{l}\text { Presentation of the Basis of Preparation } \\
\text { of the Financial Statements and Specific } \\
\text { Accounting Policies }\end{array}$ & $\begin{array}{l}\text { - the cost of creating provisions recognized by IAS } 37 \text { "Provisions, Contingent } \\
\text { Liabilities and Contingent Assets" and recoverable under the terms of a contract } \\
\text { with a third party net of the reimbursement received. }\end{array}$ & $\begin{array}{l}\text { IAS 1, } \\
\text { p.116 }\end{array}$ \\
\hline First adoption of IFRS & $\begin{array}{l}\text { In preparing its first IFRS statements, the entity uses the following assumptions by } \\
\text { IFRS } 1 \text { First-time Adoption of International Financial Reporting Standards: } \\
\text { - applies the derecognition requirements in IFRS } 9 \text { retrospectively from the date } \\
\text { the entity made the selection, provided that the information required to use IFRS } 9 \\
\text { to financial assets and financial liabilities derecognized as a result past } \\
\text { transactions was received when those transactions were initially recorded } \\
\text { (paragraph B3); } \\
\text { - applies the requirements of IFRS } 9 \text { and IAS } 20 \text { retrospectively to loans provided } \\
\text { by the government that were attracted before the date of transition to IFRS, } \\
\text { provided that the information necessary to do so was obtained at the time of initial } \\
\text { recognition this loan is recorded (clause B11); } \\
\text { - measures items of property, plant and equipment, intangible assets and } \\
\text { investment property at the date of transition to IFRS at fair value and uses this fair } \\
\text { value as the deemed cost at the date of change (paragraph D5); } \\
\text { - the cumulative translation differences for all foreign operations are assumed to } \\
\text { be nil at the date of transition to IFRSs. The gain or loss on a subsequent disposal } \\
\text { of any foreign process does not include translation differences from one currency } \\
\text { to another that arose before the date of transition to IFRS. IFRS, but has } \\
\text { subsequent differences (paragraph D13); } \\
\text { - classifies all financial liabilities as financial liabilities measured at fair value } \\
\text { through profit or loss (provided that the weakness at the transition date meets the } \\
\text { criteria in paragraph } 4.2 .2 \text { of IFRS 9) (p. D19); } \\
\text { - classifies existing contracts at the date of transition to IFRS as carried at fair } \\
\text { value through profit or loss if they meet the requirements of paragraph 5A of IAS } \\
\text { 39, and the entity classifies all similar contracts (paragraph D33). }\end{array}$ & IFRS 1 \\
\hline
\end{tabular}

A study of the activities of pension funds and insurance companies in the United States, the European Union and Asia, in terms of the ratio of reserves to assets, recorded a clear tendency towards increasing financial convergence.

The calculations made clearly show that the insurance sector of the international financial market is more susceptible to convergence; at the same time, convergence processes are traced in the pension segment. The transformation of the financial market sectors by funds of pension plans based on certain payments towards programs based on specific contributions should be noted. This transformation aims to transfer additional coverage of investment risk in the context of the flatness of financial markets. Government regulators are carrying out pension reforms and are also seeking to move corporate dangers to the individual level, which indicates the transformation of the pension services sector under the influence of convergence processes [15].

The analysis made it clear that insurance markets are the most converged; on the other hand, pension markets, under the influence of ongoing pension reforms, also tend to intensify convergence processes due to increasing competition and the desire to reduce potential risks.

A more vivid manifestation of convergence in insurance markets is also because the insurance portfolios of life insurance companies are more optimized and depend not only on the segment of the company's work but also on the structure of insurance payments for each type of insurance, forcing the company to revise its insurance portfolio in favour of more stable ones.

\section{Conclusions}

The study contains a theoretical and methodological substantiation of the directions, as well as the proposals themselves for the formation of the accounting policy of the enterprise, namely: a possible algorithm for the construction of the accounting policy of the plant by IFRS is presented, which represents the process of forming the accounting policy of the enterprise; the analysis of IFRS norms is clearly shown since this is fundamental in the formation of the accounting; analyzed IFRS, according to which options and/or variability of which are due to the inconsistency of IFRS and justified the choice of one or another option.

Recommendations have been developed on how to conduct an accounting policy article by article, taking into account international standards.

The proposed recommendations will attract more foreign investment and can facilitate the transition to IFRS for the company. 


\section{REFERENCES}

[1] Baklanova, O., Petrova, M., Koval, V. "Institutional transmission in economic development," Ikonomicheski Izsledvania, 29(1), pp. 68-91, 2020.

[2] Bashynska, I. "Management of smartization of business processes of an industrial enterprise to ensure its economic security," Schweinfurt: Time Realities Scientific Group UG (haftungsbeschrunkt), 2020, $420 \mathrm{p}$.

[3] Dobrovič, J., Rajnoha, R., Korauš, A. "Effectiveness and performance of tax system in Slovak Republic in terms of its key non-macroeconomics factors," Oeconomia Copernicana, 9(4), pp. 617-634, 2018.

[4] Fuad, Z., Agung, J. Linking Institutional Environment to the IFRS and Accounting Quality: A Proposed Framework. Universal Journal of Accounting and Finance, 9(3), 347-351, 2021. DOI: 10.13189/ujaf.2021.090308.

[5] Golov, S., Kostyuchenko, V. "Accounting for International Standards, Kyiv: Accounting," 2010, 376 p.

[6] Iankovets, T.M. "Relationship between potential, economic security and economic system development," Actual Problems of Economics, 171(9), pp. 66-73, 2015.

[7] International accounting standard 1 (IAS 1) "Presentation of financial statements".http://www.minfin.gov.ua/control/pu blish/article/main?art_id=92410\&cat_id=92408.

[8] International accounting standard 8 (IAS 8) "Accounting policies, changes in accounting estimates and errors". http://zakon2.rada.gov.ua/laws/show/929_020.

[9] International accounting standard 16 (IAS 16) "Fixed assets". http://zakon4.rada.gov.ua / laws / show / 929_014.

[10] Khomeini, O. Accounting policy in the context of methodological substantiation of the essence of definitions [Electronic resource]. HTTPS: //www.univer.km.ua/visnyk /1388.pdf.

[11] Krykavskyy, Y., Falovych, V. "The principle of the extended responsibility in the formation of multimodal transportation attractiveness," Economic Annals-XXI, 159(5-6), pp. 67-70, 2016.

[12] Kuzmenko H., Yahelska K., Artyukh O., Babich I.,Volenshchuk N., Sulimenko L. "Improved methodology of accounting and audit of payments to employees in Ukraine, " Universal Journal of Accounting and Finance, vol. 9, no. 1, pp. 44-53, 2021.

[13] Law of Ukraine "On Accounting and Financial Reporting of Ukraine". http://zakon.nau.ua/doc/?code=996-14.

[14] Podolchak, N.Y., Kulynyak, I.Y. "The method of complex estimation of risk level for lessor enterprises," Actual Problems of Economics, 142(4), pp. 144-157, 2013.

[15] Samrudha, N., B. C. M. Patnaik, Ipseeta Satpathy. Reflections on Implementation of International Financial Reporting Standards (IFRS) in the Indian Banking Industry. Universal Journal of Accounting and Finance, 8(4), 148-152, 2020. DOI: 10.13189/ujaf.2020.080407.

[16] Short, D., Welsch, G. "Fundamentals of Financial Accounting," 6th Edition, 1990, 841 p.

[17] Zagorodny, A., Vozniuk, G., Partin, G. "Accounting and audit: Terminological dictionary," Lviv: Center of Europe, 2002, $671 \mathrm{p}$. 